\section{Learning Together}

\section{A Canada-Cuba Research Collaboration to Improve the Sustainable Management of Environmental Health Risks}

\author{
Jerry Spiegel, $\mathrm{PhD}^{1-3}$ \\ Maricel Garcia, $\mathrm{PhD}^{4}$
}

\author{
Mariano Bonet, $\mathrm{MD}^{4}$ \\ Annalee Yassi, $\mathrm{MD}^{1,3,5}$
}

\section{ABSTRACT}

Objective: To build a national Cuban capacity for training environmental health professionals directly linked to the needs of policy-makers and communities.

Participants: The University of Manitoba and University of British Columbia collaborated with an established training centre in Cuba (the Instituto Nacional de Higiene y Epidemiologia - INHEM) and new centres in the Central (Santa Clara) and Eastern (Santiago) regions of the country.

\section{Setting: Cuba}

Intervention: In the mid-1990s, a comprehensive curriculum (masters and diploma programs) was collaboratively developed, applying interactive teaching methods, and was delivered through a series of workshops and other interactions in Cuba, and short-term visits to Canada by Cuban PhD students.

Outcomes: The collaboration was successful in fulfilling capacity-building targets (over 50 Masters graduates, 467 Diploma graduates, over 30 trained core faculty in all regional centres as well as new curriculum and new accredited regional programs). Alongside this, a number of collaborative community-based research projects were undertaken in all three regions (drinking water in Santiago; housing and urban renewal, and dengue control in Havana; and tourism-related effects, and effective intersectoral management of population health determinants in Santa Clara).

Conclusion: The collaboration led to adopting new strategies for challenges such as a dengue epidemic in 2002, and new research on the effectiveness of intersectoral management of risks of particular interest to both Cuban and Canadian policy-makers. It triggered an ambitious collaboration between the Canadian-Cuban team and colleagues in Ecuador in order to build a similar national network there, built on South-South and North-South links.

MeSH terms: International cooperation; public health; environmental health; interdisciplinary communication; research; teaching

La traduction du résumé se trouve à la fin de l'article.

1. Department of Health Care and Epidemiology, University of British Columbia (UBC), Vancouver, BC

2. Liu Institute for Global Issues, UBC

3. Department of Community Health Sciences, University of Manitoba, Winnipeg, MB

4. Instituto Nacional de Higiene, Epidemiología y Microbiología (INHEM), Havana, Cuba

5. Institute of Health Promotion Research, UBC

Correspondence: Dr. Jerry Spiegel, Liu Institute for Global Issues, University of British Columbia, 2036476 N.W. Marine Drive, Vancouver, BC, Canada, V6T 1Z2, Tel: 604-822-1398, Fax: 604-822-6966, E-mail: jerry.spiegel@ubc.ca

Acknowledgements: We are grateful to the Canadian International Development Agency (CIDA), the International Development Research Centre (IDRC) of Canada and the Canadian Institutes of Health Research (CIHR) for funding studies reported in this paper, and to the Association of Universities and Colleges of Canada (AUCC) for its assistance in helping to strengthen our partnership, particularly in its early stages. We would especially like to acknowledge the contributions of the many individuals in the Cuban regional centres (Havana, Santiago and Santa Clara), the communities of Cayo Hueso (Central Habana), Veguita de Galo (Santiago) and Carbarien (Villa Clara), and the Canadian teams (at the University of Manitoba and the University of British Columbia) involved in the various projects. We particularly acknowledge the role of former INHEM Director Pedro Mas in initially establishing the collaboration. Parts of this paper were included in a presentation made by Dr. Jerry Spiegel and Dr. Maricel Garcia at the AUCC-IDRC Research Colloquium in Ottawa on June 7, 2005.
G lobal health collaboration is not a one-way transfer, but a context for mutual learning. Considerable benefit is gained by each side in a "NorthSouth" partnership.

In the late 1990s, a group of Canadian and Cuban researchers initiated a collaboration to strengthen training for the management of environmental health risks in Cuba. The two parties first met several years earlier in meetings organized by the World Health Organization to stimulate a better understanding of forces that were producing negative health effects globally, as had been highlighted at the Rio United Nations Conference on Environment and Development (UNCED). ${ }^{1,2}$ As research at this time was increasingly suggesting that environmental health practitioners needed to incorporate a broader knowledge of ecosystems in their work to be effective, ${ }^{3}$ Cuba opted to apply this orientation to their plans for improving human resource capacities in this area.

This article summarizes how our international collaboration was pursued, identifies its outputs, and highlights the mutual benefit gained by both countries. In documenting the activities undertaken, attention is drawn to the reinforcing links created among regional centres, practitioners, communities and policy-makers in Cuba; to collaborative transdisciplinary research projects; and to a broader community of practice that is being established across the Americas.

\section{Background}

\section{Growing Need in Cuba}

Although Cuba is a low-income country, it is world-renowned for its healthy population and excellent health-care system. ${ }^{4,5}$ In the early 1990s, following the collapse of its trading partners in the Soviet Union and Eastern Bloc, several serious disease outbreaks $^{6}$ and the threat of an intensified United States embargo provoking even greater isolation, there were serious concerns about Cuba's capacity to maintain the infrastructure needed for good health. ${ }^{7,8}$

During this "Special Period", the Cuban Government's Ministry of Health reinforced its commitment to decentralizing health decision-making in order to better meet local needs. ${ }^{9}$ Nation-wide comprehensive skill upgrading was deemed necessary, so that each region, province and 
community would have the expertise to manage environmental health risks. As a result, the responsible agency - the Instituto Nacional de Higiene, Epidemiología y Microbiología (INHEM National Institute for Hygiene, Epidemiology and Microbiology) - was left with a daunting task.

\section{Opportunity for Collaboration Emerging in Canada}

Following the Brundtland Commission's promotion of the concept of sustainable development in the $1980 \mathrm{~s},{ }^{10}$ increasing emphasis was placed on developing a more holistic approach to environmental health. This paradigm shift coincided with growing interest among Canadian population health researchers and practitioners with regard to the influence of a wide range of population health determinants. ${ }^{11,12}$ As a result of these trends, and in light of successful Canadian experiences with applying problem-based learning to medical education, the World Health Organization engaged a Canadianled team to develop new training materials ${ }^{13-15}$ more consistent with the challenges highlighted at the 1992 UNCED conference. The United Nations Environment Programme (UNEP) contributed to this endeavour by sponsoring the involvement of developing country colleagues, with the representative from Latin America being the director of INHEM in Cuba. His personal interactions at the conference led to the collaboration described below.

An opportunity to more systematically connect the capacities and interest emerging in Canada with Cuba's strengths and objectives ultimately became available through the Canadian International Development Agency (CIDA)-funded University Partnerships in Cooperation and Development (UPCD) Program administered by the Association of Universities and Colleges of Canada (AUCC). ${ }^{16}$ In preparing for this endeavour, the partners met on several occasions to gain greater understanding of each other's strengths and needs, allowing the Canadians to then identify additional sources of funding for some research initiatives.

\section{An Interdisciplinary International Training Program}

With the explicit goal of improving human resource capacity across Cuba, INHEM

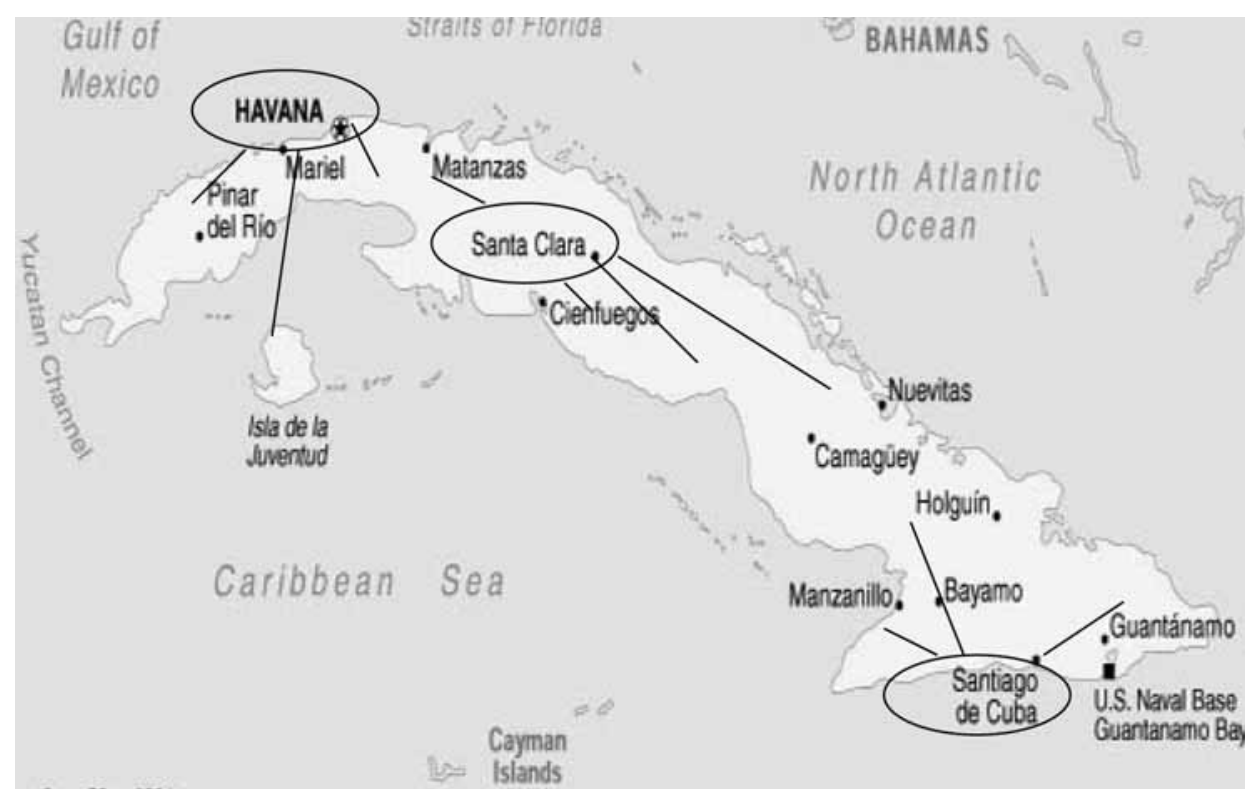

Figure 1. National Cuban Environmental Health Capacity Building Network

(based in Havana in the Western part of the island) wished to develop a national network linked to regional centres in the Eastern (Santiago de Cuba) and Central (Santa Clara) regions. ${ }^{9}$ The new centres were each to be built through partnership linking regional university-based health science training programs with provincial hygiene and epidemiology centres responsible for environmental health monitoring and management. This network (Figure 1) was designed to offer and support a Masters program (for researchers and highlevel professionals) and Diploma courses (for practitioners) based in each regional centre.

A UPCD Tier 2 project entitled "Building Interdisciplinary Capacity in Environmental Health Risk Assessment and Risk Management across Cuba" ${ }^{17}$ was collaboratively prepared and formally initiated in April 2000, with the overall objective "to strengthen institutional capacity in Cuba to teach environmental health". Secondary objectives of the project were to "establish linkages for fostering sustainable international partnerships between the participating institutions" and to "contribute to 'internationalization' of the Canadian partners".

The project incorporated a broad range of topics such as basic environmental health risk assessment and management, water and sanitation, food and agriculture, air pollution, urbanization, energy, industrialization and chemical contamination, the role of women in sustainable develop- ment, and ethical issues. The capacitybuilding component concentrated on:

i) stimulating innovative transdisciplinary problem-based learning methods and approaches;

ii) reinforcing specific areas targeted for strengthening (e.g., advanced biostatistics, economic evaluation, program evaluation and management, and a new approach to teaching environmental health using interactive teaching methods);

iii) facilitating the application of knowledge being acquired (through workshops and related research projects); and

iv) accelerating the development of future leadership and combatting the risk of isolation from new knowledge, by sending Cuban-registered PhD students to Canadian universities for broader access to resources and faculty.

As the project entered its fifth and final year, all intended outcomes were well on track to being achieved. ${ }^{18}$ For example, all core faculty members had participated in workshops in areas targeted for strengthening and were ready to deliver the core curriculum for a refined Masters Program at INHEM and new Masters programs in Santiago and Santa Clara (accreditation applications submitted). Instructors from each region have by now conducted or planned the delivery of similar curricula at their own institutions. Diploma programs on environmental health and school health (with a strong environmental health component) have also been delivered through 


\section{TABLE I}

\section{Capacity-building Program Highlights}

1. Diploma Program graduates

Environmental health (Total: 204)

- Cuba: Western region (87); Central region (98); Eastern region (19)

- Ecuador (54)

- School health (Total: 263)

- Cuba: Western region (59); Central region (25); Eastern region (26)

- Ecuador (35); Other Latin American countries (118)

2. An international workshop on teaching methods

- Professors (3 Canadian; 2 Cuban)

- Trainers in workshop (32 Cuban; 8 international from 5 countries)

- Inclusion of innovative teaching methods (problem-based learning, role plays, etc.) in curricula, with CDs and web-accessible case studies and other exercises for teaching

3. Workshop training

- Select topics (advanced biostatistics, economic evaluations, risk management, critical appraisal methods, etc.)

33 Masters program professors: Western (17); Central (6); Eastern (6).

4. Production of materials

- e.g., guide for conducting Health Impact Assessments in Environmental Assessment ${ }^{19}$ produced at a multi-stakeholder workshop

5. Improvement of core Masters program at INHEM

- 55 students graduating in the first 4 years of the UPCD project

6. Development of new Masters programs

- For accreditation in 2 new regional centres

7. PhD Training

7 Cubans in semesters in Canada as part of their doctorate programs

8. Considerable new opportunities for Canadian students

- 2 Masters theses and 1 post-doctoral research project ${ }^{20}$ successfully completed in Cuba

- 50 medical students from UBC and the University of Manitoba in a summer elective program in Santa Clara focussed on primary care organization and population health

\section{TABLE II}

\section{Research Program Highlights}

Project

- Effectiveness of a community-based approach to safe drinking water in Santiago de Cuba

- Urban ecosystem health indicators

- Building interdisciplinary capacity in environmental health risk assessment and risk management across Cuba

- Building a partnership to better assess the impact of housing improvements on health: A trans-disciplinary global health research project based in Cuba

- Developing a research program on globalization, social organization and health

- Globalization, Social Organization and Health: A collaborative Cuban-Mexican-Canadian pilot study of the impact of tourism on gender and health in coastal communities

- Developing methodology to understand the Cuban paradox: A pilot study on the determinants of health in Cuba

- Intersectoral collaboration in securing excellent health outcomes: A multi-methods study of the approach to environmental health in Cuba's health care system

- Applying an ecosystem approach to sustainably prevent and control dengue in Centro Habana, Cuba

- Building an eco-health community of practice: Linking networks and nodes in Latin America and the Caribbean

- Sustainably managing environmental health risks in Ecuador

CIDA: Canadian International Development Agency

CIHR: Canadian Institutes of Health Research

IDRC: International Development Research Centre

distance-education methods for students across Cuba, as well as other Latin American countries. Outputs have been impressive, as shown in Table I.

\section{A collaborative research program}

As the training effort was being prepared, a companion collaborative research program was also being developed. In 1998-99, the first step was to address the supply of safe drinking water in the Eastern Region (Santiago) of the country, an area suffering from drought amid the difficult economic conditions. $^{21}$ This area was identified by the Cubans as one of their most pressing problems, and the Canadian partners arranged for funding through the International Development Research Centre (IDRC) to support related research on the feasibility of applying a low-cost technology (slow sand filtration). As the partnership deepened, the needs of an inner-city community in Central Havana also became the subject of research. Local decision-makers and the community had approached INHEM for assistance in evaluating how improvements in housing and living conditions in a stressed urban ecosystem could improve health and wellbeing. The "ecosystem approach to human health", which formed the core conceptual framework of the UPCD Tier 2 training program, provided an ideal opportunity for trainees to apply their developing skills. ${ }^{22}$ This project, conducted between 1999 and 2001 , provided a rich data-set for demonstrating how indicators to facilitate analysis of the impact of interventions can be developed collaboratively by communities and decision-makers. ${ }^{23-25}$ It inspired numerous publications, ${ }^{22-28}$ with the research effort earning an award from the Cuban Academy of Sciences. ${ }^{29}$

A project impact of considerable interest was the application of the risk-management framework to an outbreak of dengue fever in 2001-2. Through prompt action to control breeding sites, and effective identification and isolation of viremic individuals, the outbreak was effectively controlled..$^{30}$ In the aftermath of this crisis, both policymakers and the community expressed interest in developing a more sustainable control program, and a follow-up study in Central Havana was funded to apply an integrated surveillance program with active community involvement. ${ }^{31}$

The above research projects were documented as interactive case studies for training purposes in the curriculum being developed, completing the process of building capacity for both creating knowledge and achieving impact. Sustainability was further enhanced in November 2004 with the founding of a national network in Cuba (Red Nacional de Capacitación en Salud Ambiental) dedicated to the application of the ecosystem approach to health.

The recently established Canadian "Global Health Research Initiative" 32 has provided great support for international collaborations, specifically allowing Cuban and Canadian trainees to further collaborate with local decision-makers and communities in addressing challenges of knowledge translation. Table II lists the research projects completed or being conducted collaboratively by the team, with the active participation of many Canadian and Cuban students. 


\section{Broader collaborations}

While the collaborative "human-resource training program" in Cuba is primarily focussed on Cuban communities, the experience sparked the interest of other Latin American partners. For example, numerous Ecuadorians have participated in the project's diploma program, as illustrated in Table I. Following the involvement of four Ecuadorians at the international workshop, the feasibility of pursuing a similar program in Ecuador was explored. A proposal was developed building on existing materials and the successful Cuban experience, while incorporating new themes of particular interest in Ecuador, such as disasterpreparedness and indigenous health. A consortium of Ecuadorian universities was assembled, with research projects in vulnerable communities identified as central to the new training program. Other partners in this initiative include a network of over 10 centres and institutes at the University of British Columbia, INHEM in Cuba and the Instituto Nacional de Salud Publica (INSP - National Institute of Public Health) in Mexico. This project is just getting started, but has already received the British Columbia Centre for International Education Innovation Award for the strength of its design! ${ }^{33}$

With growing recognition that effective management of non-medical health determinants is key to addressing the health needs of Canadians, ${ }^{34}$ the team is also beginning a 3-year initiative entitled "Inter-Sectoral Collaboration in Securing Excellent Health Outcome: A multimethods study of the approach to environmental health in Cuba's healthcare system". The overriding question to be studied is how Cuba is pursuing the intersectoral management of environmental health risks through integration with community-based health services, and how evidence is being generated and used to support this (Figure 2).

CONCLUSION: CHALLENGES AND OPPORTUNITIES FOR MUTUAL LEARNING

Much has been accomplished through this international collaboration. Positive impacts throughout Cuba include greater human-resource capacity and improved environmental risk-management practices,

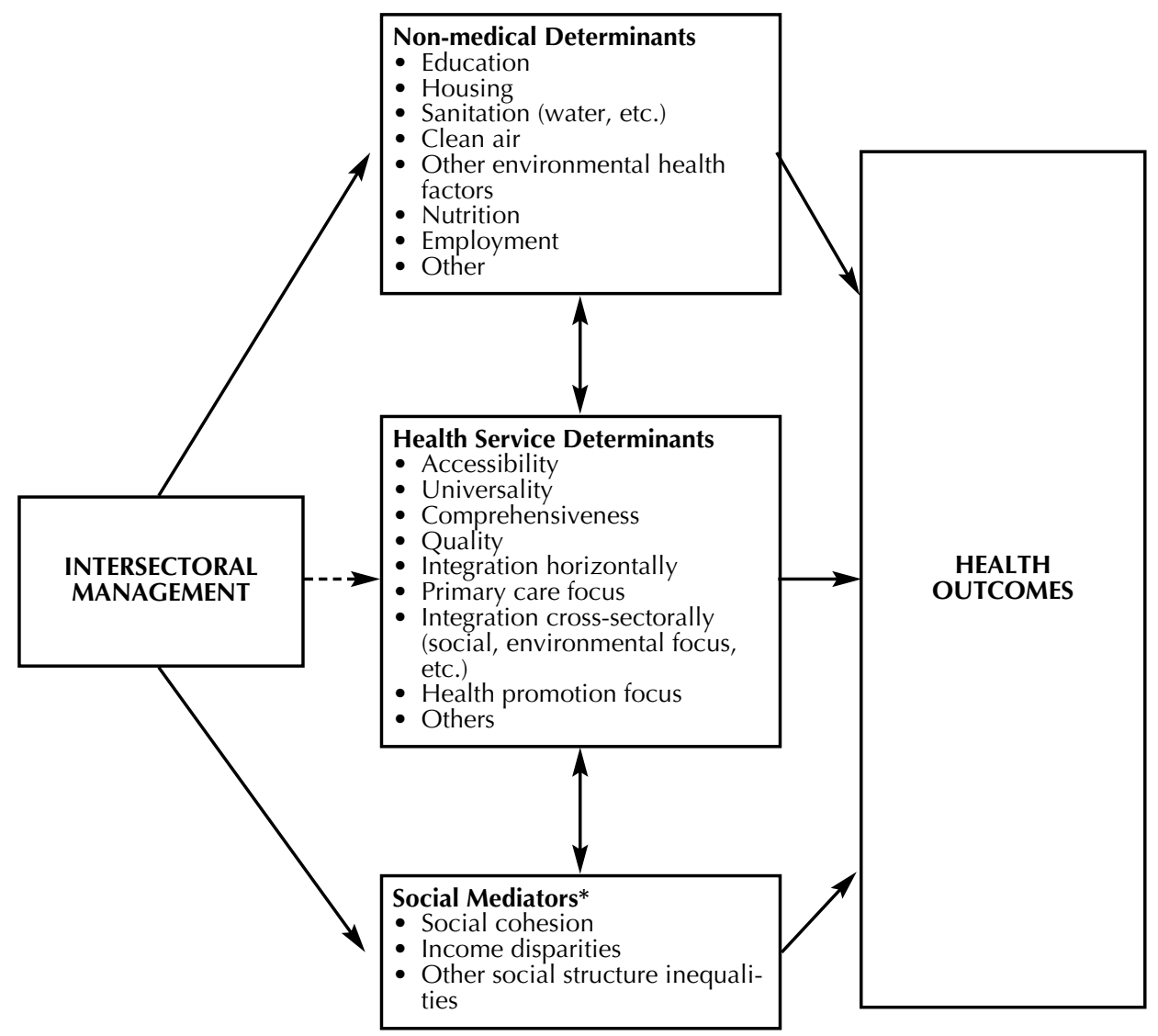

Figure 2. Conceptual model for examining how intersectoral management contributes to effective management of health determinants*

* Income is not included as a determinant in the model at this time, as increasingly the literature (e.g., McLeod et al. ${ }^{35}$ ) is suggesting that it is "what income can buy" and/or the psychosocial perceptions associated with income that are crucial. The former factors are included in the non-medical determinants (and to some extent, the health service determinants) and the latter factors are included in the social mediators, thus income is not shown in the model.

The variables to be examined in this study are highlighted and in bold.

as witnessed in the proactive management of challenges such as dengue. The experience is now being used as a resource for further programs in Cuba and elsewhere in Latin America. And through such experience, efforts are underway to extend the learning to Canada, where considerable conceptual development often has outstripped practice, but where there is a growing interest in pursuing interdisciplinary efforts to better tackle environmental health challenges.

Above all, the experience has been rewarding for the partners directly involved. Beyond considerable personal enrichment, the UPCD training program experience was of great value in establishing a CIHR-funded strategic training program entitled "Partners in Community Health Research", to train Canadian researchers in working more effectively with communities.

In retrospect, the success of the collaboration has been based around a relatively simple foundation, underscoring what is required to overcome international, crosscultural and interdisciplinary challenges: a common vision, common understanding, and a mutual respect for each partner's commitments and capacities. A common vision in this case was provided by the "ecosystem approach to human health", a paradigm for promoting transdisciplinarity, empowerment and equity. ${ }^{36}$ The trust fostered through working together accentuated the importance of a common understanding of the interests, needs and talents of individual parties. The pressures faced by the Canadian university-based researchers were very different from those 
faced by communities seeking results, or the Cuban partner institutions held accountable to address that community's basic needs. The management framework used to trace inputs and activities through to outputs, outcomes and impacts enabled the team to take stock of its shortcomings, and mutually develop strategies for improvement.

At the time the collaboration was first formed, funding support opportunities were limited. Since then, recognition of the importance of transdisciplinarity and knowledge translation has increased dramatically, both in Canada and world-wide. As these themes are central to such collaborations, initiatives such as the Global Health Research Initiative (linking IDRC, CIDA, CIHR and Health Canada) and the Canadian Coalition for Global Health Research can now contribute to similar successes in a broad range of settings. ${ }^{37}$

During the 2001-2 dengue crises in Cuba, a massive coordinated effort was undertaken to meet the challenge. In Canada, the frustrating experience of the 2003 SARS outbreaks stimulated the establishment of the Public Health Agency of Canada and renewed attention towards strengthening public health capacity. As Canada and Cuba are both explicitly seeking to strengthen institutional capacities for dealing with common public health challenges, we have an excellent opportunity to build on our respective strengths and contribute to world knowledge in an increasingly critical area.

\section{REFERENCES}

1. WHO. Global Strategy: Health, environment and development: Approaches to drafting country-level strategies for human well being under Agenda 21. Geneva, Switzerland: World Health Organization, 1993. WHO/HEH/93.1.

2. WHO. Our Planet Our Health. Geneva: WHO, 1992.

3. Lebel J, Forget G. An ecosystem approach to human health. Int J Occup Environ Health 2001;7:S3-S36.

4. Spiegel JM, Yassi A. Lessons from the margins of globalization: Appreciating the Cuban health paradox. J Public Health Pol 2004;25(1):96-121.

5. MacDonald TH. A Development Analysis of Cuba's Health Care System Since 1959: Studies in Health and Human Services. Lewiston, NY: Edwin Mellen Press, 1999.

6. Kirkpatrick AF. The US attack on Cuba's health. CMAJ 1997;157(3):281-84.

7. Garfield R, Santana S. The impact of the economic crisis and the US Embargo on health in Cuba. Am I Public Health 1997;87(1):15-20.

8. WHO. Analysis of the Public Health Sector in Cuba. Progress Report. Havana City. MINSAP/PAHO/WHO, 1995.
9. García M, Yassi A, Spiegel J, Alegret M, Carrió C. Colaboración cubano-canadiense para desarrollar capacidades en evaluación y manejo de riesgos de Salud Ambiental en Cuba. Submitted to Revista de Salud Publica (Mexico), 2005.

10. Brundtland GH (Ed.). The United Nations World Commission on Environment and Development: Our Common Future. Oxford, UK: Oxford University Press, 1987.

11. Lalonde M. A New Perspective on the Health of Canadians: A Working Document. Ottawa, ON: Ministry of Health and Welfare, 1974.

12. Evans RG, Barer ML, Marmor TR (Eds.). Why are Some People Healthy and Others Not? The Determinants of Health of Populations. New York, NY: Aldine de Gruyter, 1994.

13. Yassi A, Kjellström T, de Kok T, Guidotti T. Basic Environmental Health. 2001. Oxford University Press, New York. (Draft edition 1997). Available as CD text (Spanish language): Yassi A et al. (2002). Salud Ambiental Básica. La Habana, Cuba: SOFTCAL

14. Weinger M. Teacher's Guide on Basic Environmental Health. New York: Oxford University Press, 1999. WHO/SDE/PEHE/99.5. Available online at http://www.who.int/docstore/peh/archives/beh/behtgp1.pdf (Accessed on May 15, 2005).

15. Yassi A, Kjellström T, DeKok T, Weinger M. Teaching basic environmental health in universities utilizing an interdisciplinary holistic approach and interactive learning methods. Ecosystem Health 1997;3(3):143-53.

16. UPCD. University Partnerships in Cooperation and Development Home Page. Association of Universities and Colleges of Canada. Ottawa, Canada, 2005. Available online at: http://www.aucc.ca/upcd-pucd/index_e.html (Accessed on May 15, 2005).

17. UPCD. Building Interdisciplinary Capacity in Environmental Health Risk Assessment and Risk Management across Cuba. Association of Universities and Colleges of Canada. Ottawa, Canada, 2005. Available online at: http://oraweb.aucc.ca/pls/cupid/show_project_e?
project_no_in=38/S61268-263/E (Accessed on May 15, 2005)

18. Spiegel J, García M. Links Upon Links: A Canada-Cuba partnership to build sustainable capacity for managing environmental health risks through international collaboration. Presented at the AUCC-IDRC Research Colloquium. Ottawa, Canada. June 6-7, 2005. Proceedings to be published in November 2005

19. García M, Barceló C, Diego F, Fernández N, Junco R, et al. Evaluación del impacto en salud de proyectos de inversión. Instituto Nacional de Higiene Epidemiología y Microbiología. Havana, Cuba, Editorial Académica, 2003.

20. Loucks E, Aldama A, Ibarra AM, Barceló Pérez C, Guzmán Piñeiro R, Tate R. Vivienda y salud en residentes en el municipio de Centro Habana. Revista Cubana de Higiene y Epidemiologia 2004;42(1).

21. Bonnefoy P. Coping with water crisis in Cuba. Ottawa, ON: International Development Research Centre, 2002. Available online at: http://web.idrc.ca/en/ev-5496-201-1 DO TOPIC.html (Accessed on May 15, 2005).

22. Yassi A, Mas P, Bonet M, Tate RB, Fernandez N, Spiegel J, et al. Applying an Ecosystem Approach to the Determinants of Health in Centro Habana. Ecosystem Health 1999;5(1):3-19.

23. Spiegel J, Bonet M, Yassi A, Molina E, Concepción M, Mas P. Developing ecosystem health indicators in Centro Habana: A community-based approach. Ecosystem Health 2001;7(1):15-26

24. Spiegel J, Bonet M, Yassi A, Tate B, Concepción M, Cañizares M. Evaluating the effectiveness of multi-component intervention to improve health in an inner-city Havana community. Int J Occup Environ Health 2003;9(2):118-27.

25. Spiegel J, Bonet M, García M, Ibarra AM, Tate RB, Yassi A. Building capacity in Central Havana to sustainably manage environmental health risk in an urban ecosystem. EcoHealth 2004;1(Suppl 2):SU120-SU130.

\section{RÉSUME}

Objectif : Créer à Cuba une capacité nationale de formation de professionnels en salubrité de l'environnement directement liée aux besoins des décideurs et des collectivités.

Participants : L'Université du Manitoba et l'Université de la Colombie-Britannique ont collaboré avec un centre de formation bien établi de Cuba (I'Instituto Nacional de Higiene y Epidemiologia INHEM) et de nouveaux centres dans la région centrale (Santa Clara) et la région orientale (Santiago) du pays.

Lieu : Cuba

Intervention : Au milieu des années 1990, on a élaboré par un effort concerté un programme d'études global (menant à la maîtrise et à divers diplômes) qui appliquait des méthodes d'enseignement interactives. On a mis ce programme à exécution au moyen d'une série d'ateliers et d'autres interactions à Cuba, et d'une série de brefs séjours au Canada par des doctorantes et des doctorants cubains.

Résultats : Cette collaboration a atteint ses objectifs de renforcement des capacités (plus de 50 détenteurs et détentrices de maîtrises, 467 diplômées et diplômés, plus de 30 membres du corps professoral de base formés dans tous les centres régionaux, nouveau programme d'études et nouveaux programmes régionaux agréés). En parallèle, des projets concertés de recherche communautaire ont été entrepris dans les trois régions (eau potable à Santiago; logement, renouvellement urbain et lutte contre la dengue à La Havane; et effets touristiques et gestion intersectorielle efficace des déterminants de la santé de la population à Santa Clara).

Conclusion : La concertation a mené à l'adoption de nouvelles stratégies pour relever des défis comme l'épidémie de dengue de 2002 et à de nouvelles études sur l'efficacité de la gestion intersectorielle des risques qui intéressent particulièrement les décideurs cubains et canadiens, et elle a été l'élément déclencheur d'une collaboration ambitieuse entre l'équipe canado-cubaine et ses collègues en Équateur, qui veulent construire un réseau national semblable dans leur pays à partir de liens Sud-Sud et Nord-Sud. 
26. Yassi A, Fernandez N, Fernandez A, Bonet M, Tate RB, Spiegel JM. Evaluation of community participation in a multi-sectoral intervention to address health determinants in an inner-city community in Central Havana. J Urban Health 2003;80(1):61-80.

27. Fernández N, Tate R, Bonet M, Cañizares $M$, Mas P, Yassi A. Health risk perception in the inner city community of Centro Habana, Cuba. Int J Occup Environ Health 2000;6:34-43.

28. Tate RB, Fernandez N, Yassi A, Cañizares M, Spiegel J, Bonet M. Change in health risk perception following community intervention in Central Havana, Cuba. Health Promot Int 2003;18(4):279-86.

29. IDRC. Case Study: Cuba: Housing and Human Capital in Cuba. Health: An Ecosystem Approach. 2003. Available online at: http://web.idrc.ca/ uploads/user-S/10588197541Ecohealth Casestudy_10_e.pdf (Accessed on May 15, 2005).

30. Spiegel J, Yassi A, Tate R. Dengue in Cuba: Mobilization against Aedes aegypti. Lancet Infect Dis 2002;2:207-8.

31. García M, Bonet M, Spiegel J, Concepción M, Tate RB, Yassi A. Applying an ecosystem approach to sustainably prevent and control dengue in Centro Habana, Cuba. Presented at: International Forum on Ecosystem Approaches to Human Health. May 18-23, 2003. Montreal, Canada.

32. Spiegel JM, Labonte R, Hatcher-Roberts J, Girard J, Neufeld V. Tackling the 10-90 gap: A report from Canada. Lancet 2003;362(9387):917-18.

33. Full documentation on this project is available at www.cih.ubc.ca (Accessed on December 10, 2005).

34. Romanow R. Now's the time to stand up for medicare. Globe and Mail June 10, 2005.

35. McLeod CB, Lavis JN, Mustard CA, Stoddart GL. Income inequality, household incomes, and health status in Canada: A prospective cohort study. Am J Public Health 2003;93:1287-93.

36. Lebel J. Health: An Ecosystem Approach. Ottawa: International Development Research Centre, 2003.

37. Neufeld V, Spiegel J. Canada and global health research: 2005 update. Can J Public Health 2006;97(1):39-41.

Received: June 16, 2005

Accepted: November 23, 2005

\section{Coming Events / Activités à venir}

To be assured of publication in the next issue, announcements should be received by January 15, 2006 and valid as of February 28, 2006. Announcements received after January 15, 2006 will be inserted as time and space permit.

Pour être publiés dans le prochain numéro, les avis doivent parvenir à la rédaction avant le $\mathbf{1 5}$ janvier 2006 et être valables à compter du 28 février 2006. Les avis reçus après le 15 janvier 2006 seront insérés si le temps et l'espace le permettent.

$17^{\text {th }}$ International Conference on the Reduction of Drug-related Harm

Hear and Now: The PEER Conference

British Columbia Centre for Excellence in HIV/AIDS, IHRA, Providence Health Care

30 April-4 May $2006 \quad$ Vancouver, BC

Contact:

Harm Reduction 2006 Conference Secretariat c/o Advance Group

Toll-free: 1-800-555-1099

Tel: 604-688-9655 Fax: 604-685-3521

E-mail: info@harmreduction2006.ca

www.harmreduction2006.ca

6PHA 97 $7^{\text {th }}$ Annual Conferencel (1) $97^{\mathrm{e}}$ conférence annuelle de l'ACSP What Determines the Public's Health? People, Places, Politics / Qu'est-ce qui détermine la santé du public?

CPHA in partnership with Canadian Institute for Health Information - Canadian Population Health Initiative, Canadian Institutes of Health Research - Institute of Population and Public Health, Public Health Agency of Canada 28-31 May/mai 2006 Vancouver, BC/C.-B. Contact/contacter :

CPHA Conference Department/

Service des conférences de l'ACSP

Tel/Tél : 613-725-3769

Fax/Téléc : 613-725-9826

www.cpha.ca

$16^{\text {th }}$ World Conference on Disaster Management The Changing Face of Disaster Management: A Global Perspective

Presented by the Canadian Centre for

Emergency Preparedness

18-21 June 2006

Toronto, ON

Contact:

Alysone Will

Conference Co-ordinator

Absolute Conference and Events

Tel: (416) 595-1414 Ext:. 224

Fax: (416) 979.1819

E-mail: coord@wcdm.org

Canadian Nurses Association (CNA) 2006

Biennial Convention

Advancing Technology and Preserving Caring in

Nursing

Hosted by the Saskatchewan Registered Nurses'

Association

18-21 June $2006 \quad$ Saskatoon, SK

Contact:

www.cna-aiic.ca
Healing Our Spirit Worldwide

The $5^{\text {th }}$ Gathering

Presented by International Indigenous Council for HOSW

6-11 August 2006

Edmonton, Alberta

Contact:

Tel: (780) 447-4675

Fax: (780) 488-6717

Toll Free: 1-866-999-HOSW

(1-866-999-4679)

E-mail: info@hosw.com

The 6th International Conference on Priorities in Health Care

Presented by the International Society on

Priorities in Health Care

20-22 September 2006

Toronto, Ontario

Contact:

Carolyn Farrell

Tel: (416) 946-0088

Fax: (416) 978-1911

E-mail: carolyn.farrell@utoronto.ca

Annual Meeting of the Royal College of

Physicians and Surgeons of Canada

Presented by the Royal College of Physicians and Surgeons of Canada

28-30 September 2006

Ottawa, Ontario

Contact:

Tel: $1-800-668-3740$

Fax: (613) 730-8252

E-mail: meetings@rcpsc.edu

IDSA $44^{\text {th }}$ Annual Meeting

Presented by Infectious Diseases Society of

America

12-15 October 2006

Toronto, Ontario

Contact:

Tel: (703) 299-0200

APHA $134^{\text {th }}$ Annual Meeting and Exposition

Public Health and Human Rights

American Public Health Association

4-8 November 2006

Boston, MA

Contact:

www.apha.org 